\title{
Molecular identification of cryptic diversity in species of cis-Andean Mylossoma (Characiformes: Serrasalmidae)
}

\section{Nadayca T. B. Mateussi, Carla Simone Pavanelli \& Claudio Oliveira}

To cite this article: Nadayca T. B. Mateussi, Carla Simone Pavanelli \& Claudio Oliveira (2017) Molecular identification of cryptic diversity in species of cis-Andean Mylossoma (Characiformes: Serrasalmidae), Mitochondrial DNA Part A, 28:5, 778-780, DOI: 10.1080/24701394.2016.1180515

To link to this article: https://doi.org/10.1080/24701394.2016.1180515

曲 Published online: 09 May 2016.

Submit your article to this journal

Џ Article views: 99

View Crossmark data ð 


\title{
Molecular identification of cryptic diversity in species of cis-Andean Mylossoma (Characiformes: Serrasalmidae)
}

\author{
Nadayca T. B. Mateussi ${ }^{\mathrm{a}, \mathrm{b}, \mathrm{c}}$, Carla Simone Pavanelli ${ }^{\mathrm{a}, \mathrm{c}}$ and Claudio Oliveira ${ }^{\mathrm{b}}$ \\ ${ }^{a}$ Coleção Ictiológica, Núcleo De Pesquisas Em Limnologia, Ictiologia E Aquicultura, Universidade Estadual De Maringá, Maringá, Brazil; \\ bLaboratório De Biologia E Genética De Peixes, Departamento De Morfologia, Universidade Estadual Paulista, Distrito De Rubião Junior, \\ Botucatu, Brazil; 'Programa De Pós-Graduação Em Ecologia De Ambientes Aquáticos Continentais, Universidade Estadual De Maringá, \\ Maringá, Brazil
}

\begin{abstract}
Mylossoma is a Serrasalmidae genus with only two current valid species in the cis-Andean region but with several available names, today considered as junior synonymous. Morphological information combined with single-locus DNA sequences of cytochrome c oxidase I gene analysed by Barcode Index Number and General Mixed Yule Coalescent model were used in the present study to help the recognition of Operational Taxonomic Units (OTUs) in cis-Andean Mylossoma and discuss species boundaries within the genus. Five OTUs were recognized based on both morphological and molecular approaches. The analysis using the Barcode Index Number resulted in five OTUs, with $M$. duriventre being split in one unity in the Amazon, one in the Orinoco, one in Paraná-Paraguay and one in Tocantins-Araguaia which is coherent with our morphological results.
\end{abstract}

\section{ARTICLE HISTORY}

Received 16 April 2015 Accepted 16 April 2016

Published online 5 May 2016

\section{KEYWORDS}

DNA barcoding; GMYC; neotropical; species complex

\section{Introduction}

Mylossoma is a Serrasalmidae genus with only three valid species, one trans-Andean: M. acanthogaster from Maracaibo Lake and two cis-Andean: $M$. aureum and $M$. duriventre from Amazon, Orinoco, Tocantins-Araguaia and Paraná-Paraguay river basins. Despite of the well-established monophyly of Mylossoma, problems in the species recognition still exist (Machado-Allison \& Castillo 1992). Considering the wide distribution of cis-Andean Mylossoma, in the present work we used partial sequences of the gene cytochrome c oxidase I mitochondrial gene (COI) and morphological information to test the hypotheses that this group represents more than two Operational Taxonomic Units (OTUs).

\section{Material and methods}

A total of 64 fishes were collected at 17 sites along the cisAndean South America in accordance with local laws. Total DNA was obtained from muscle samples (DNeasy Blood \& Tissue kit). COI segments were amplified with the primers Fish F1 and Fish R2 (Ward et al. 2005). The amplification was performed in a thermal cycler PCR using $25 \mu$ of a solution containing $16.1 \mu \mathrm{l}$ of distilled water, $2.5 \mu \mathrm{l}$ dNTP $(8 \mathrm{mM}), 2.5 \mu \mathrm{l}$ of $10 \times$ buffer, $1.2 \mu \mathrm{l}$ of each primer $(10 \mu \mathrm{M})$ and $0.5 \mu \mathrm{l}$ DNA Polymerase ( 5 units $/ \mu \mathrm{l}$ ). Each PCR cycle consisted basically of denaturation for $5 \mathrm{~min}$ at $95^{\circ} \mathrm{C}$, annealing for $45 \mathrm{~s}$ at $52^{\circ} \mathrm{C}$ and extension for $1 \mathrm{~min}$ at $68^{\circ} \mathrm{C}$. This cycle was repeated 30 times and the final step included a final extension for $5 \mathrm{~min}$ at $68^{\circ} \mathrm{C}$. The DNA was marked with the Big Dye Terminator
Cycle Sequencing Standard Version 3.1 Kit (Applied Biosystems) and sequenced on an automated DNA sequencer. Consensus sequences were obtained from the forward and reverse sequences using Geneious 4.8 program (Kearse et al. 2012).

OTUs were identified using traditional morphological identification, the Barcode Index Number (BIN) (Ratnasingham \& Hebert 2013) and the General Mixed Yule Coalescent program (GMYC) (Pons et al. 2006) with two models: (1) Birth-Death and (2) Yule. Ultrametric trees were constructed with relaxed molecular clock using a lognormal time distribution through BEAUTi and BEAST programs (Drummond et al. 2012). A total of $100,000,000$ trees were sampled each 10,000 generations. All topologies sampled below the asymptote $(2,000,000$ generations) were discarded as part of a burn-in procedure. The remaining trees were used to build a majority consensus tree in TreeAnnotator program (Rambaut \& Drummond 2011). The clusters were identified with GMYC program, using the APE and SPLITS packages in R-studio program (2012).

\section{Results and discussion}

Barcode sequences with more than $500 \mathrm{pb}$ were obtained for 64 specimens. After alignment and edition, the final matrix had 675 characters, of which 545 positions were conserved and 130 were variable. Sequences were deposited in the BOLD (BMYL002-14/066-14; BMYL067-15/068-15) and GenBank (KR070896-KR070959). Mylossoma aureum and different groups of $M$. duriventre differ between 1.4 and $9.0 \%$ of

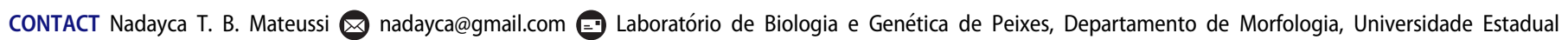
Paulista, Distrito de Rubião Junior, 18618-970, Botucatu, São Paulo, Brazil 
Table 1. Genetic distance (Kimura-2-parameter + gamma) among the primary Mylossoma lineages studied.

\begin{tabular}{lcccccc}
\hline & Colossoma & Group 1 & Group 2 & Group 3 & Group 4 & Group 5 \\
\hline Colossoma & $\mathrm{n} / \mathrm{c}$ & & & & & \\
Group 1 & $0.1802 \pm 0.0258$ & $0.0042 \pm 0.0018$ & & & & \\
Group 2 & $0.1909 \pm 0.0266$ & $0.0867 \pm 0.0142$ & $0.0044 \pm 0.0016$ & & & \\
Group 3 & $0.1874 \pm 0.0260$ & $0.0904 \pm 0.0152$ & $0.0771 \pm 0.0133$ & $0.0025 \pm 0.0017$ & & \\
Group 4 & $0.1842 \pm 0.0257$ & $0.0909 \pm 0.0156$ & $0.0728 \pm 0.0137$ & $0.0141 \pm 0.0049$ & $0.0034 \pm 0.0017$ & $0.0040 \pm 0.0014$ \\
Group 5 & $0.1774 \pm 0.0249$ & $0.0841 \pm 0.0147$ & $0.0715 \pm 0.0134$ & $0.0574 \pm 0.0113$ & $0.0531 \pm 0.0113$ & $0.0037 \pm 0.0239$ \\
Piaractus & $0.1558 \pm 0.0232$ & $0.1569 \pm 0.0219$ & $0.1643 \pm 0.0241$ & $0.1510 \pm 0.0229$ & $0.1499 \pm 0.0226$ & $0.0019 \pm 0.0018$ \\
\hline
\end{tabular}

The main diagonal (bold) shows the intragroup values. Colossoma and Piaractus samples were used for comparison. (Group 1: M. aureum; 2: M. duriventre from the Orinoco River Basin; 3: M. duriventre from the Paraná-Paraguay rivers Basin; 4: M. duriventre from the Tocantins-Araguaia rivers Basin; 5: M. duriventre from the Amazon River Basin.)

(a)

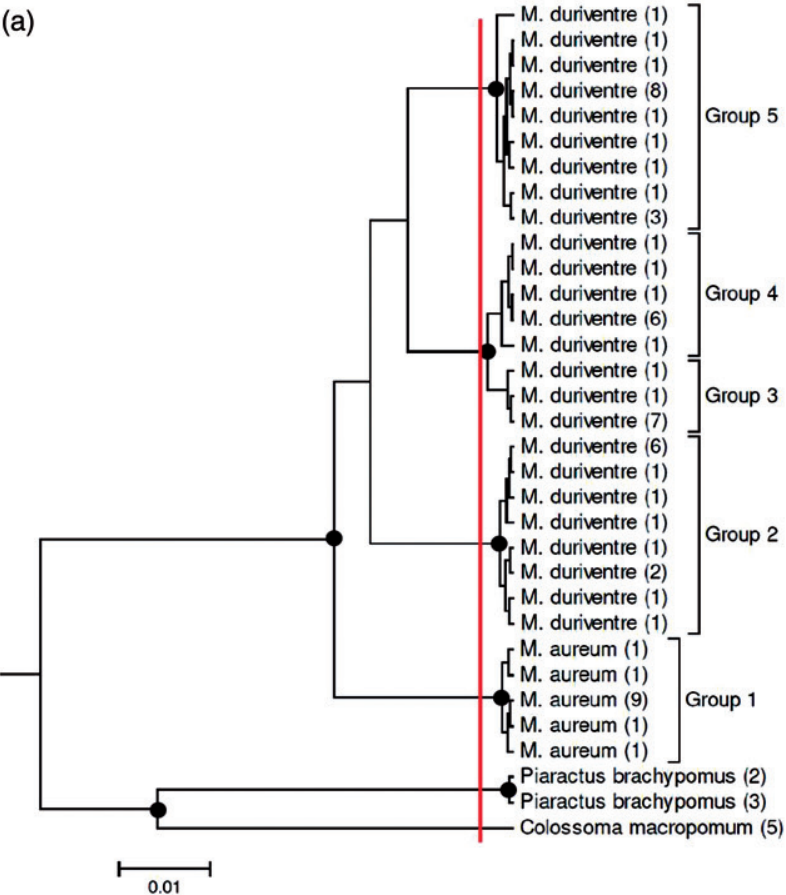

(b)

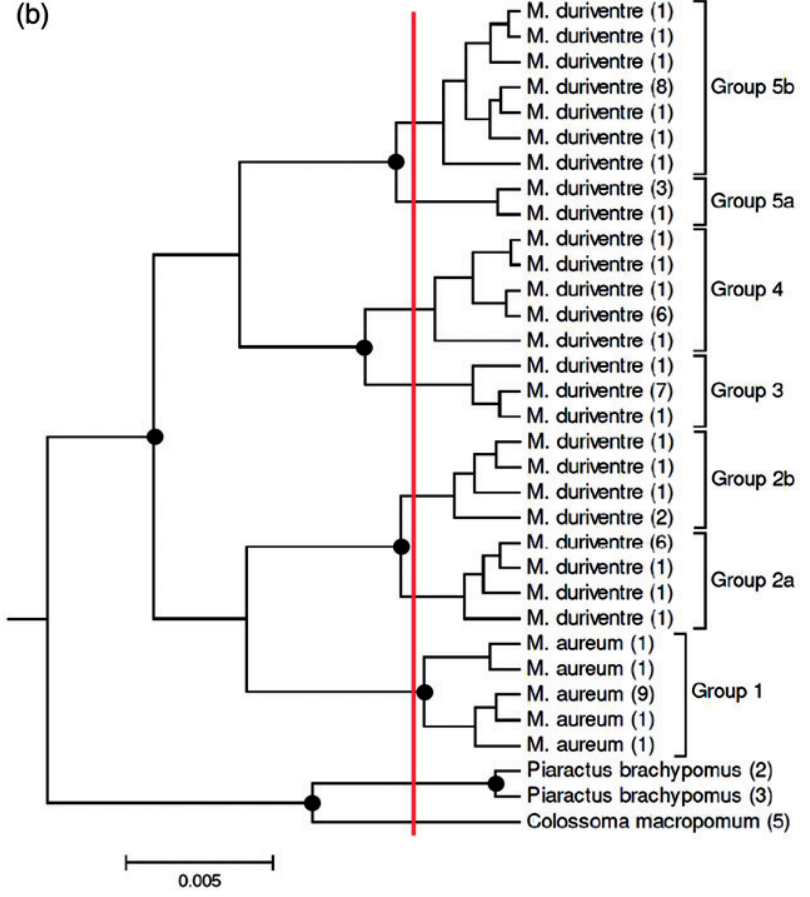

Figure 1. Bayesian phylogenetic trees of Mylossoma obtained with COI data. The black dots in the node branches represent posterior probabilities greater than $95 \%$. The vertical line in the trees shows the transition point from Yule to a coalescent branching process in the analyses of all sequences. This was estimated by using the single-threshold model in the GMYC test with the Birth-Death (a) and Yule (b) speciation models in BEAST. The values in parentheses show the number of haplotypes sequenced.

$\mathrm{K} 2 \mathrm{P}+$ gamma distance (Table 1). The threshold time obtained in the GMYC analysis was $-2.85 \times 10^{-3} \mathrm{~T}$.

Our results indicate that BIN and GMYC approaches (Birth-Death model) agree with the occurrence of only one OTU in Mylossoma aureum (Figure 1) but the Yule model shows the presence of two groups, both from Amazonas River Basin, separated by a genetic distance of 0.0042 . This small genetic difference should be studied more carefully in the future. Mylossoma aureum was described by Spix and Agassiz (1829) and can be differentiated from other Mylossoma species by the absence of anal spines, with ventral spines not attached to the anal fin. Thus, in this case both methods (molecular and morphological) can differentiate the species.

Our data suggest that the widely distributed $M$. duriventre represents more than one OTU. The Birth-Death model suggests the occurrence of four OTUs. Two of these OTUs (groups 2 and 5 - Figure 1) were divided when we used the Yule model, but the genetic distance between the group 2a and $2 \mathrm{~b}$ was 0.0052 and the genetic distance between group $5 \mathrm{a}$ and $5 \mathrm{~b}$ was 0.0047 . The groups 3 and 4 were divided when we used the Yule model and also in the BIN analysis. A perfect correlation was observed between the groups identified using the BIN model and their geographic distribution. Thus, group 2 represents the samples from the Orinoco River basin, group 3 from the Paraná-Paraguay River basin, group 4 from the Tocantins-Araguaia River basin and group 5 from Amazon River basin. Mylossoma duriventre was described by Cuvier (1818), but actually under this name we have seven junior synonymous (Jégu 2003). A taxonomic review should be performed to analyse the correct species attributions for the OTUs.

During the speciation process, the affected characters are highly diversified, in order that the changes do not occur at the same time or on a regular order and boundaries between new species become increasingly evident as time goes on (Queiroz 2007). However, at the beginning of this process known as Grey Zone - the boundaries between species are hardly identified, making the limits between species very subjective and dependent on species concepts applied (Queiroz 2007). The results obtained for Mylossoma indicate that the 
genetic change may precede or not the morphological change. Morphological change preceding substantial genetic change can be observed in the case of $M$. duriventre groups 3 and group 4, which present low genetic divergence $(d=0.0141)$ but can be differentiated morphologically. Although their genetic divergence is low when compared to other species, according to Ward (2009) among fishes divergences ranging from one to $1.5 \%$ are much more likely to be congeners that conspecifics. The case of genetic change preceding the morphology change can be observed in $M$. duriventre group 2 and $M$. duriventre group 5, which were separated into more than one OTU with over 7\% of K2P distance and cannot be clearly separated morphologically (our unpublished data). Also, these OTUs do not appear as a monophyletic group. In this case, the existence of cryptic species is evident, since the morphological data do not agree with genetic data. This pattern found in $M$. duriventre groups 2 and 5, can be caused by convergence related to selective pressures triggered by similar environmental conditions.

\section{Conclusions}

Our data demonstrate the efficacy of DNA barcoding for discriminating known species and to flag new ones. We justify the use of DNA barcode sequences as part of the formal description of species, since these data can be useful when morphological characters are insufficient or too weak to define species.

\section{Acknowledgments}

The authors are grateful to Gleisy Avelino Santos for her help during the extraction and sequencing procedures and to Valéria Nogueira Machado from Universidade Federal do Amazon and Dr. Mauro Nirchio from Universidad de Oriente for their donation of tissues.

\section{Disclosure statement}

The authors report no conflicts of interest and are alone responsible for the content and writing of the paper.

\section{Funding information}

This research was supported by the Brazilian agencies CNPq (Conselho Nacional de Desenvolvimento Científico e Tecnológico), CAPES/PROEX (Coordenação de Aperfeiçoamento de Pessoal de Nível Superior/Programa de Excelência Acadêmica) and FAPESP (Fundação de Amparo à Pesquisa do Estado de São Paulo).

\section{References}

Cuvier G. 1818. Sur le poissons du sous-genre Myletes. Annls Mus Hist Nat Paris. 4:444-456.

Drummond AJ, Suchard MA, Xie D, Rambaut A. 2012. Bayesian phylogenetics with BEAUti and the BEAST 1.7. Mol Biol Evol. 29:1969-1973.

Jégu M. 2003. Subfamily Serrasalminae: pacus and piranhas. In: Reis $R$, Kullander SO, Ferraris Jr CJ, editors. Check list of the freshwater fishes of South and Central America. Porto Alegre: Edipucrs. p. 182-196.

Kearse M, Moir R, Wilson A, Stones-Havas S, Cheung M, Sturrock S, Buxton S, Cooper A, Markowitz S, Duran C, et al. 2012. Geneious basic: an integrated and extendable desktop software platform for the organization and analysis of sequence data. Bioinformatics. 28:1647-1649.

Machado-Allison A, Castillo O. 1992. Estudios sobre la sistematica de la subfamília Serrasalminae. IV. El genero Mylossoma: bases para la revision del grupo en America del Sur. Acta Biol Venez. 13:1-34.

Pons J, Barraclough TG, Gomez-Zurita J, Cardoso A, Duran DP, Hazell S, Kamoun S, Sumlin WD, Vogler AP. 2006. Sequence-based species delimitation for the DNA taxonomy of undescribed insects. Syst Biol. 55:595-609.

Queiroz K. 2007. Species concepts and species delimitation. Syst Biol. 56:879-886.

Rambaut A, Drummond AJ. 2011. TreeAnnotator version 1.6.2; [cited 2014 Dec 01]. Available from: http://beast.bio.ed.ac.uk/treeannotator.

Ratnasingham S, Hebert PDN. 2013. A DNA-based registry for all animal species: the Barcode Index Number (BIN) system. PLoS One. 8:e66213.

R-Studio. 2012. R-Studio: integrated development environment for R (version 0.96.122) [computer software]. Boston; Retrieved May 20, 2012; [cited 2014 Dec 01]. Available from: http://www.rstudio.org.

Spix JB, Agassiz L. 1829. Selecta genera et species piscium quos in itinere per brasiliam annos mdcccxvii-mdcccxx jussu et auspiciis maximiliani josephi. I. Colleget Et Pingendso Curavit Dr J B De Spix. Monachii. 2:83-138.

Ward RD. 2009. DNA barcode divergence among species and genera of birds and fishes. Mol Ecol Resour. 9:1077-1085.

Ward RD, Zemlak TS, Innes BH, Last PR, Hebert DN. 2005. DNA barcoding Australia's fish species. Philos Trans $\mathrm{R}$ Soc Lond B Biol Sci. 360:1847-1857. 